\title{
Valorization of fruits and vegetables waste through green extraction of bioactive compounds and their nanoemulsions-based delivery system
}

\author{
Anuradha Saini, Parmjit Singh Panesar ${ }^{*}$ and Manab Bandhu Bera
}

\begin{abstract}
Fruits and vegetables, a significant segment of food sector, generate large volume of wastes annually. They constitute an excellent source of several valuable components (carotenoids, polyphenols, etc.), also known as bioactive compounds. These bioactive compounds have a positive impact on health and are known to modulate the metabolic processes as well as influence the cellular activities in the human health due to their antioxidant, anti-cancer, antiinflammation, anti-allergenic and anti-atherogenic properties; depending upon the pathway and their bioavailability in the body. Despite this, some of these compounds are hydrophobic in nature and therefore are less bioavailable in the body. However, with the technological advancements like nanoemulsions, their solubility, stability and functional properties can be enhanced. This review provides the comprehensive information about the green extraction techniques and innovative delivery system such as nanoemulsions for bioactive compounds generated from fruits and vegetables waste.
\end{abstract}

Keywords: Fruits and vegetables waste, Bioactive compounds, Extraction, Nanoemulsions

\section{Introduction}

Over the last decade, food processing industry has observed a tremendous growth and is one of the fastest growing sectors throughout the world. However, significant quantities of wastes are generated during the processing. According to the reports, approximately $20 \%$ of the wastes out of total 14 million metric tons (MMT) are generated during the processing of food and drink, its distribution and retail (Parfitt et al. 2010). In contrast to the other food processing sector, higher amounts of wastes, equivalent to $25-30 \%$, are obtained from fruits and vegetables $(\mathrm{F} \& \mathrm{Vs})$ industries that generally include peels, rind, seeds, core, rag, stones, pods, vine, shell, skin, pomace, etc. (Ajila et al. 2010). It was estimated that around 55 MMT waste is released during every

\footnotetext{
*Correspondence: pspanesarrr@yahoo.com

Food Biotechnology Research Laboratory, Department of Food

Engineering \& Technology, Sant Longowal Institute of Engineering

and Technology, Longowal, Punjab 148106, India
}

processing steps, which includes processing of F\&Vs (5.5 $\mathrm{MMT})$, canning as well as freezing (6 MMT), wine processing (5-9 MMT) and others. The largest producers of these wastes are Philippines, China, India and the USA (FAO 2014; Schieber et al. 2001; Panouillé et al. 2007). These wastes, if not disposed or treated, cause serious environmental hazards due to the emission of various green house gases during decomposition (Vilariño et al. 2017). Hence, in order to circumvent these issues, there is a need for the valorization of wastes into various valueadded products or extraction of bioactive compounds having various functional benefits.

Bioactive compounds or components can be defined as those food products or dietary supplements that have beneficial health effect on the host, besides meeting the basic nutritional requirements (Studdert et al. 2011). These are known to exhibit antioxidant, anti-microbial or antiinflammatory activities on the host; however, these properties vary with their bioactivity, chemical structure, amount of dosage and others (Abdelkarim 2014). Being abundant in 
bioactive components, these can be extracted from wastes that can be further utilized for the development of functional foods. Different extraction techniques have been investigated for the value addition of wastes. Various compounds, such as carotenoids, phytosterols, omega-3 fatty acids, curcumin, oil-soluble vitamins, have been extracted using various techniques from wastes. However, due to the hydrophobicity and bioavailability of some bioactive compounds, there is a requirement of a potential delivery system, which may help in increasing their functionality to perform specific functions in the body.

In context to this, nanoemulsions have gained great attention and have been used as a delivery system for not only enhancing the stability, solubility as well as bioavailability of bioactive compounds in body, but also protecting them from adverse environmental conditions $(\mathrm{pH}$, light, moisture, temperature, etc.). Nanoemulsions are used to reduce the separation of particles via sedimentation or creaming and improve the appearance (clear suspension) as well as other physico-chemical properties of food systems in which bioactive compounds are incorporated. The schematic representation of the extraction of different bioactive compounds from F\&Vs wastes, delivery system and its applications thereof is depicted in Fig. 1. In view of the above, this review provides comprehensive information regarding the extraction of bioactive compounds from F\&Vs waste and their improved delivery system for applications in food industries.

\section{Bioactive compounds in fruits and vegetables waste}

Fruits and vegetables are vital food commodities, which are required for fulfilment of the daily nutritional requirements of humans. In food industry, huge amount of waste is being produced that is characterized on the basis of biological oxygen demand as well as chemical oxygen demand. It is rich in different bioactive components; therefore, rather than considering as waste, these can be utilized for the recovery of valuable compounds, thereby leading to the zero-waste concept. Zero-waste concept is an effective strategy that allows effective valorization of the generated agro-industrial wastes to valueadded products, which have several applications in food sector as colouring agents, antioxidative agents, preservatives and many more.

These wastes provide the wide array of bioactive compounds such as carotenoids (lutein and zeaxanthin), flavonoids (hesperetin, quercetin, genistein and kaempferol) and phenolic acids (Table 1). These phytochemicals vary in their polarity, solubility, molecular size, bioavailability and metabolic pathways. According to the Dietary Guidelines for Americans (2010), people should eat at least 4 serving of fruits and 5 serving of vegetables

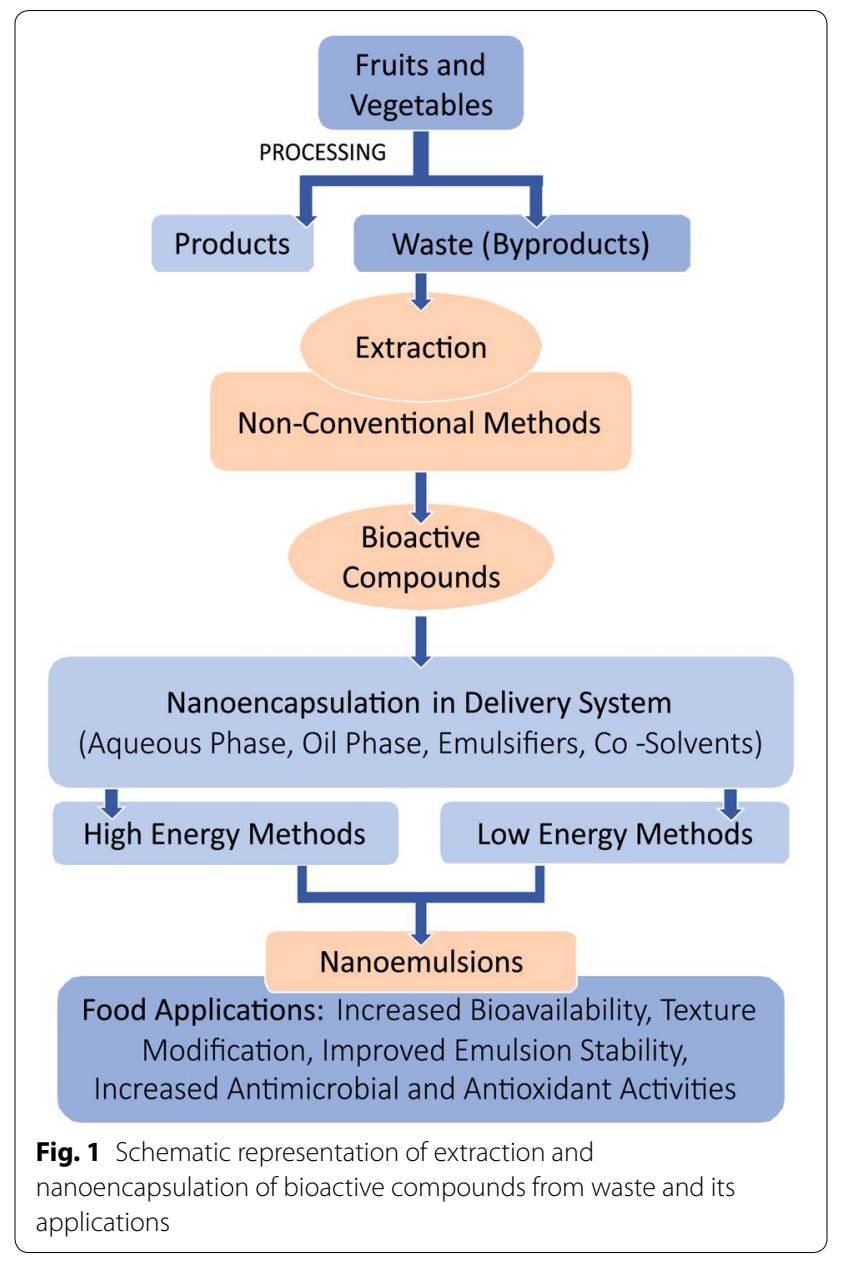

based on a 2000-kcal diet, but there is the huge difference between recommendation and consumption value (Liu 2013). The diet that constitutes large proportion of F\&Vs has a significant role in reducing the risk of various diseases such as cardiovascular disease and cancer (Genkinger et al. 2004; Freedman et al. 2008). Generally, in $F \& V s$ waste, the bioactive compounds with their natural antioxidant potency are higher than pulp. It indicates that F\&Vs wastes also have good potential for natural antioxidants. These bioactive compounds can be added in the food either directly or by using different nanoencapsulation techniques such as nanoemulsions which further improve the functional value of these food products. Furthermore, these compounds can be used in nutraceutical, cosmetic and pharmaceutical industries.

\section{Extraction of bioactive compounds by green technology}

The bioactive compounds can be extracted by using both conventional and non-conventional technologies, each having their own advantages and disadvantages. However, in the recent years, green extraction technology, 
Table 1 Bioactive compounds of fruits and vegetables waste

\begin{tabular}{|c|c|c|c|}
\hline $\begin{array}{l}\text { Categories } \\
\text { (Phytochemicals) }\end{array}$ & Metabolites/compounds & Sources & References \\
\hline \multirow[t]{12}{*}{ Phenolics } & $\begin{array}{l}\text { Ferulic acids, tryptophane, p-coumaric acids, cyclodopa-glucoside } \\
\text { derivatives }\end{array}$ & Red beet peels & Kujala et al. (2000) \\
\hline & Flavonol glycosides, anthocyanins, catechins, stilbenes & Grapes pomace & Schieber et al. (2001) \\
\hline & Ferulic acid, caffeic acid, p-coumaric acid & Apple peels & Leontowicz et al. (2007) \\
\hline & $\begin{array}{l}\text { Epicatechin, catechin, cyanidin 3-glucoside, gallic acid } \\
\text { Chlorogenic acid }\end{array}$ & Blueberry peels & Deng et al. (2012) \\
\hline & Catechin, galangin, homogentisic acid & Guava peels & \\
\hline & Gallic acid, kaempferol, cyanidin 3-glucoside & Guava seeds & \\
\hline & Cyanidin 3-glucoside, catechin, chlorogenic acid, homogentisic acid & Avocado stones & \\
\hline & $\begin{array}{l}\text { Epicatechin, gallic acid, chlorogenic acid, catechin, cyanidin 3-gluco- } \\
\text { side, homogentisic acid, protocatechuic acid, -p-hydroxybenzoic acid }\end{array}$ & Grapes seeds & \\
\hline & $\begin{array}{l}\text { Hydroxybenzoic acid, caffeic acid-O-glucoside, caffeoylputrescine, di- } \\
\text { ferulic acid, p-coumaric acid, coumaric acid-o-glucoside }\end{array}$ & Garlic peels & Kallel et al. (2014) \\
\hline & Gallic, sinapic, caffeic, myricetin, ferulic, ellagic acid & Purple star apple peels & Moo-Huchin et al. (2015) \\
\hline & $\begin{array}{l}\text { Ellagic acid, gallic acid, punicalin, punicalagin } \\
\text { Caffeic acid, chlorogenic acid, ferulic acid, sinapic acid, p-coumaric acid }\end{array}$ & $\begin{array}{l}\text { Pomegranate peels } \\
\text { Different citrus varieties peels }\end{array}$ & $\begin{array}{l}\text { Živković et al. (2018) } \\
\text { Wang et al. (2008) }\end{array}$ \\
\hline & $\begin{array}{l}\text { Delphinidin-3-rutinoside-5-glucoside, cyanidin-3-rutinoside, delphi- } \\
\text { nidin-3-rutinoside, malvidin-3-rutinoside-5-glucoside, petunidin- } \\
\text { 3-rutinoside }\end{array}$ & Eggplant peels & Ferarsa et al. (2018) \\
\hline Flavonoids & $\begin{array}{l}\text { Naringin, hesperidin, neohesperidin, diosmin, luteolin, sinensetin, rutin, } \\
\text { kaempferol, quercetin }\end{array}$ & Different citrus varieties peels & Wang et al. (2008) \\
\hline \multirow[t]{2}{*}{ Carotenoids } & a-carotene, $\beta$-carotene & Carrot pomace & Schieber et al. (2001) \\
\hline & $\begin{array}{l}\text { Lycopene } \\
\beta \text {-carotene, zeaxanthin, lutein, } \beta \text {-cryptoxanthin } \\
\text { Neochrome, lutein, } \beta \text {-cryptoxanthin, } \beta \text {-citraurin, luteoxanthin, cryp- } \\
\text { tochrome, } \xi \text {-carotene }\end{array}$ & $\begin{array}{l}\text { Tomato seeds } \\
\text { Different citrus varieties peels } \\
\text { Different citrus varieties peels }\end{array}$ & $\begin{array}{l}\text { Rozzi et al. (2002) } \\
\text { Wang et al. (2008) } \\
\text { Agócs et al. (2007) }\end{array}$ \\
\hline
\end{tabular}

also known as non-conventional technology, has become the recent area of research. Owing to the high yield, reduced process time, high-quality products and less waste generation, these green technologies have replaced the traditional conventional technologies.

Various green technologies based on enzyme (enzymeassisted extraction), pressurized liquid (pressurized liquid extraction), microwave (microwave-assisted extraction), ultrasound (ultrasound-assisted extraction), pulsed electric field (pulsed electric field assisted extraction) and supercritical fluid (supercritical fluid extraction) have been explored for the extraction of bioactive compounds. The effectiveness of these techniques varies with the properties of the source matrix, its chemical structure and process parameters like solvent, pressure, time and temperature (Azmir et al. 2013). Description of the various green extraction techniques is given in Table 2.

\section{Supercritical fluid extraction}

Extraction of compounds by this technique is carried out by using solvents above the critical point. This critical point can be defined as "the specific temperature (Tc) or pressure $(\mathrm{Pc})$ point, above which gas and liquid do not exist as separate phase". These fluids exhibit the properties of both liquids in terms of density and salvation power as well as gas (viscosity, diffusion and surface tension) that facilitates higher yield within short time (Ameer et al. 2017). The basic system for supercritical fluid extraction (SFE) includes mobile tank consisting of $\mathrm{CO}_{2}$, pump, solvent vessel, oven, controller and a trapping vessel (Azmir et al. 2013).

In contrast to the traditional methods, supercritical $\mathrm{CO}_{2}$ extraction, higher yields of naringin were obtained from citrus paradise using ethanol as a modifier $(15 \%$ by weight) at the same process conditions, viz. $58.6{ }^{\circ} \mathrm{C}$ temperature and 9.5 MPa pressure (Giannuzzo et al. 2003). Further, extraction of phenolic compounds from rice wine lees had been investigated by both soxhlet extraction (SE) and SFE. In contrast to SE, SFE technique was found to be efficient in terms of reduced extraction time ( $1 \mathrm{~h}$ as compared to $6 \mathrm{~h}$ while using SE) and less ethanol requirement (1/10th of the quantity used in SE), thereby resulting in maximum yield of $43 \%$ phenols ( $\mathrm{Wu}$ et al. 2009).

Carbon dioxide is the most commonly used solvent in food sector since it is safe and critical conditions are 
Table 2 Comparison of different green extraction techniques along with their examples

\begin{tabular}{|c|c|c|c|c|c|}
\hline \multirow[t]{2}{*}{ Summary } & \multicolumn{4}{|l|}{ Examples } & \multirow[t]{2}{*}{ References } \\
\hline & Bioactive compounds & Source & Solvent/enzyme & Yield & \\
\hline \multicolumn{6}{|c|}{ Supercritical fluid extraction (SFE) } \\
\hline \multirow{4}{*}{$\begin{array}{l}\text { Generally, } \mathrm{CO}_{2} \text { is used } \\
\text { Conducted under room } \\
\text { temperature and at high } \\
\text { pressure } \\
\text { Environment friendly } \\
\text { Time-saving process } \\
\text { Recycle and reuse of the } \\
\text { supercritical fluid }\end{array}$} & Lycopene & Tomato waste & Liquid $\mathrm{CO}_{2}$ & 729.98 mg/kg & Kehili et al. (2017) \\
\hline & Total phenolic content & Orange pomace (dry) & $\begin{array}{l}\text { Pure ethanol } \\
\text { Ethanol/water (9:1) }\end{array}$ & $\begin{array}{l}21.2 \mathrm{GAE} / \mathrm{g} \text { of extract } \\
20.7 \mathrm{GAE} / \mathrm{g} \text { of extract }\end{array}$ & Espinosa-Pardo et al. (2017) \\
\hline & Polyphenol content & Seed fraction & & $7.7 \mathrm{mgGAE} / \mathrm{g}$ & Manna et al. (2015) \\
\hline & & $\begin{array}{l}\text { Skin fraction } \\
\text { (Grape pomace) }\end{array}$ & & $11.9 \mathrm{mgGAE} / \mathrm{g}$ & \\
\hline \multicolumn{6}{|l|}{ Pulsed electric field } \\
\hline \multirow{3}{*}{$\begin{array}{l}\text { Less time-consuming } \\
\text { Conducted under room } \\
\text { temperature or heat and } \\
\text { at atmospheric pressure } \\
\text { Water, aqueous and non- } \\
\text { aqueous solvents along } \\
\text { with moderate quantity } \\
\text { Reduction in energy cost }\end{array}$} & Anthocyanin & Grape by-products & Water and ethanol & $\begin{array}{l}14.05 \text { mg Cy-3-glu eq./g dry } \\
\text { matter }\end{array}$ & Corrales et al. (2008) \\
\hline & $\begin{array}{l}\text { Total phenolic } \\
\text { Total anthocyanin content }\end{array}$ & Blueberry press cake & $\begin{array}{l}50 \% \text { ethanol and } 0.5 \\
\mathrm{HCl}\end{array}$ & $\begin{array}{l}+63 \% \\
+78 \%\end{array}$ & $\begin{array}{l}\text { Bobinaitè et al. (2015) } \\
\text { Boussetta et al. (2012) }\end{array}$ \\
\hline & Polyphenols & Grape seeds & Ethanol & $9 \mathrm{~g} / 100 \mathrm{~g} \mathrm{GAE}$ & \\
\hline \multicolumn{6}{|l|}{ Microwave-assisted extraction } \\
\hline \multirow{3}{*}{$\begin{array}{l}\text { Cost-effective technique } \\
\text { Water, aqueous and non- } \\
\text { aqueous solvents along } \\
\text { with moderate quantity } \\
\text { or none } \\
\text { High yield and short } \\
\text { extraction time } \\
\text { Operated under room } \\
\text { temperature and at } \\
\text { atmospheric pressure }\end{array}$} & Total phenolic & Red grape pomace & Water & $\begin{array}{l}52,645 \text { ppm GAE in dry } \\
\text { extract }\end{array}$ & Drosou et al. (2015) \\
\hline & Total phenolic content & C. sinensis peels & $\begin{array}{l}\text { Acetone in water } \\
(20-80 \%)\end{array}$ & 12.09 mgGAE/g DW & Nayak et al. (2015) \\
\hline & Total carotenoid yield & Gac peels & Ethyl acetate & $262.3 \pm 3.5 \mathrm{mg} / 100 \mathrm{~g} \mathrm{DW}$ & Chuyen et al. (2017) \\
\hline \multicolumn{6}{|l|}{ Ultrasound-assisted extraction } \\
\hline \multirow{3}{*}{$\begin{array}{l}\text { Reduction in the time, } \\
\text { energy and power } \\
\text { usage } \\
\text { Conducted under room } \\
\text { temperature or heat and } \\
\text { at atmospheric pressure }\end{array}$} & $\begin{array}{l}\text { Carotenoids (all-trans- } \\
\text { lycopene, } \beta \text {-carotene) }\end{array}$ & Tomato pomace & Hexane and ethanol & 7.49 to $14.08 \mathrm{mg} / 100 \mathrm{~g} \mathrm{dw}$ & Luengo et al. (2014) \\
\hline & Total phenolic & Red grape pomace & Water & $\begin{array}{l}\text { 50,959 ppm GAE in dry } \\
\text { extract }\end{array}$ & Drosou et al. (2015) \\
\hline & Naringin (Flavonoid) & Grapefruits solid waste & Ethanol & $24-36 \mathrm{mg} / \mathrm{g} \mathrm{dw}$ & Garcia-Castello et al. (2015) \\
\hline \multirow{2}{*}{$\begin{array}{l}\text { Water, aqueous and non- } \\
\text { aqueous solvents along } \\
\text { with moderate quantity } \\
\text { Higher yield } \\
\text { Use of renewable plant } \\
\text { resources } \\
\text { Quick return of investment } \\
\text { Safety and security } \\
\text { Reduction of unit opera- } \\
\text { tions }\end{array}$} & $\begin{array}{l}\text { Phenols, antioxidant, } \\
\text { anthocyanins }\end{array}$ & Grape seeds & Ethanol & $\begin{array}{l}5.41 \mathrm{mg} \mathrm{GAE} / 100 \mathrm{ml} \\
2.29 \mathrm{mg} / \mathrm{ml}\end{array}$ & Ghafoor et al. (2009) \\
\hline & Natural colour & Pomegranate rinds & Water & $20 \%$ & Sivakumar et al. (2011) \\
\hline \multicolumn{6}{|l|}{ Enzyme-assisted extraction } \\
\hline \multirow{3}{*}{$\begin{array}{l}\text { High rate of extraction } \\
\text { Used water as solvent } \\
\text { (Eco-friendly) } \\
\text { High cost of enzyme for } \\
\text { large volume of samples } \\
\text { Unsuitable for heat-labile } \\
\text { compounds }\end{array}$} & Carotenoids & Pumpkin & Pectinex UltraSP ${ }^{\circledR}$ & $2 \mathrm{mg} / 100 \mathrm{~g}$ & Ghosh and Biswas (2015) \\
\hline & Anthocyanins & Crocus sativus & Pectinex $^{\circledR}$ & $6.7 \mathrm{mg} / \mathrm{g}$ & Lotfi et al. (2015) \\
\hline & Carotenoid & Capsicum annuum & $\begin{array}{l}\text { Viscozyme } L^{\circledR} \text {, cellulose } \\
\text { and pectinase }\end{array}$ & $41.72-279.83 \mathrm{mg} / 100 \mathrm{~g}$ & Nath et al. (2016) \\
\hline
\end{tabular}

easily attainable $\left(30.9{ }^{\circ} \mathrm{C}\right.$ and 73.8 bars). However, the major limitation lies in its low polarity, which can be improved by using polar solvents (methanol, ethanol, dichloromethane, acetone, etc.) acting as modifiers that improve its solvating power and enhance its extraction efficiency by minimizing the interactions between the analyte and the matrix. Apart from this, low diffusibility of the solvent into the matrix, extended extraction time, high-pressure requirement, expensive infrastructure, variation in terms of consistency and reproducibility during continuous process are some of the other major limitations that hinder the scalability of this technique (Ameer et al. 2017). 


\section{Ultrasound-assisted extraction}

The range of 20 to $2000 \mathrm{kHz}$ is generally applied for ultrasound-assisted extraction (UAE). It is a low-cost and simple technique that is based upon two facts: one being the diffusion across the cell walls and other being the rinsing of the contents after cell disruption. It works on the principle of cavitation in which the waves cause the expansion and compression of the matrix that causes permeabilization of the cell wall and results in an increased yield of desired product. Several studies have revealed other possible mechanisms of UAE, which includes intensification of mass transfer, breakdown of the particles, increase in the accessibility of the solvents towards the cells. This technique has been widely used for the processing of liquid-liquid or liquid-solid samples. However, the efficiency of this technique is influenced by several factors such as pressure, temperature, frequency as well as time of sonication (Kentish and Feng 2014; Shen et al. 2017).

Amidst all, frequency is one of the major factors that have a profound effect not only on the yield, but also on the properties of the compound. It has been reported that extraction using more than $20 \mathrm{kHz}$ energy affected the physico-chemical properties of the phytochemicals with the formation of free radicals (Shen et al. 2017; Kentish and Feng 2014).

The influence of the UAE technique on the extraction of tannins from Avaram shell (Cassia auriculata) at $100 \mathrm{~W}$ was studied by Sivakumar et al. (2014). In contrast to the magnetic stirring, UAE resulted in the improvement of the yield by $160 \%$ at $100 \mathrm{~W}$. This may be attributed due to the improved mass transfer of cell components and leaching of tannins by ultrasound. Similarly, the yield of phenolic acids by UAE was $64.28 \mu \mathrm{g} / \mathrm{g}$ (caffeic acid), $1513 \mu \mathrm{g} / \mathrm{g}$ (ferulic acid) and $140 \mu \mathrm{g} / \mathrm{g}$ ( $p$-coumaric acid), etc., which was higher than in the conventional maceration extraction, for example, $31.70 \mu \mathrm{g} / \mathrm{g}$ (caffeic acid), $763 \mu \mathrm{g} / \mathrm{g}$ (ferulic acid) and $63.1 \mu \mathrm{g} / \mathrm{g}$ ( $p$-coumaric acid), etc. Extraction at higher temperature for prolonged time has a negative impact on the yield of phenolic compounds from citrus peels (Ma et al. 2008). Apart from this, the comparative study of maceration and UAE technique indicated that maceration $(72 \mathrm{~h})$ took more time than UAE $(1 \mathrm{~h})$ for extraction of phenolic compounds present in Punica granatum fruits (Chanfrau and Armas 2014). Furthermore, extraction of polysaccharides from black mulberry fruit resulted in highest yield of 3.13\% that depicted the efficiency of the ultrasonic technique (Chen et al. 2015).

In contrast to conventional solvent techniques, UAE has certain advantages in terms of low temperature, which results in less thermal degradation of bioactive compounds and reduced extraction time. Overall, it is a cost-effective method at laboratory scale; however, in order to evaluate the process cost, there is a need for the scalability of this technique (Virot et al. 2010). In food industry, UAE is generally being used for different applications, such as sterilization, extraction and preservation (Zhang et al. 2018).

\section{Microwave-assisted extraction}

Microwave-assisted extraction (MAE) method involves the electromagnetic radiations, transmitted as waves in the frequency range from $300 \mathrm{MHz}$ to $300 \mathrm{GHz}$, among which the common frequency used is $2450 \mathrm{MHz}$ that is equivalent to almost 600-700 Watts energy. This technique is based on the principle that energy absorbed during the passage of microwaves through the medium converts into the thermal energy, which facilitates the processing (Zhang et al. 2011).

This technique results in the disruption of the hydrogen bonds, when a solvent placed in contact with the sample is heated, which results in the dipole rotation of the molecules and migration of the ions that allow the diffusion of the solvent, thus leading to the dissolution of the components (Datta et al. 2005). Other probable mechanisms involves the evaporation of the moisture within the cells, which induces high pressure on the cell wall and therefore changes the physical properties of the materials as well as modifies the porosity of biomaterials. This increases the penetration of the solvent, which further improves the yield of biomaterials (Routray and Orsat 2011).

Extraction of flavonoids from Terminalia bellerica plant using microwave resulted in the maximum yield of $82.74 \%$, which was quite higher than that of conventional method where flavonoids content was 63.75\% (Krishnan and Rajan 2016). MAE is an endothermic and spontaneous process; therefore, the operating conditions, such as temperature as well as solvent and feed ratio, have a strong influence on the yield of the flavonoids. Further, hesperidin yield was found to be $47.7 \mathrm{mg} / \mathrm{g}$ (86.8\%) from the skin of citrus unshiu fruit by microwave-assisted extraction (Inoue et al. 2010). During extraction, temperature had a profound effect on the yield, since extraction above $140{ }^{\circ} \mathrm{C}$ temperature decreased the hesperidin content due to the interference of the other solubilized substances that inhibited the formation of hesperidin crystals. Moreover, in contrast to the mature peels, immature peels have about 3.1 times higher hesperidin content. The highest yield of phenolic compounds from chokeberries was 420.1 equivalents $\mathrm{mg}$ gallic acid/100 g obtained at $300 \mathrm{~W}$ for $5 \mathrm{~min}$ (Simić et al. 2016). Moreover, extraction of silibinin from Silybum marianum using MAE was conducted and the highest extract yield was 97.3\% which was higher than in the conventional extraction techniques (Dhobi et al. 2009). Similarly, phenolic 
compounds from apple pomace have also been extracted and different parameters like solubility, dielectric constant, dissipation factor $(\delta)$ and solvent had a significant effect on yield (Chandrasekar et al. 2015). Furthermore, Alupului et al. (2012) had reported the higher recovery of flavonoids by MAE (74\%) as compared to conventional solvent extraction $(70.5 \%)$ technique and indicated that MAE method is efficient than the other techniques.

In the recent years, MAE has gained tremendous attention and is considered one of the excellent green extraction techniques due to the enhanced productivity, reduced extraction time, less solvent requirement, simplicity and low set-up costs, thereby reducing the overall cost of the process (Moreira et al. 2017).

\section{Pulsed electric field}

Pulsed electric field (PEF) is a non-thermal process that allows the application of direct current. In this technique, high-voltage pulses are passed through the materials placed within the electrodes for short time, usually in the range of microseconds to milliseconds. In this, when an electric current passes through the suspension of cells, cell structure is destroyed and thus the molecules separate according to their respective charge (Bryant and Wolfe 1987). This method can be operated in both modes: either in a batch or in a continuous mode (Puértolas et al. 2010). Various factors, such as field strength, energy, pulse number, properties of the materials and temperature, affect the extraction yield and therefore must be considered while designing a process (Heinz et al. 2003).

PEF has been used for the extraction of phenolic compounds and anthocyanins from Merlot skin (Delsart et al. 2012). Moreover, application of PEF on grape skin before maceration not only improves the stability of bioactive compounds during vinification, but also shortens the time of extraction (López et al. 2008). In contrast to the untreated control sample, PEF treatment along with the maceration technique (carried out during vinification) not only improved the colour as well as anthocyanin content but also resulted in an enhanced polyphenol content. Therefore, the application of PEF treatment during winemaking process could reduce the maceration time during vinification and also help in the improvement of wine quality. Further, the yield of phenolic compounds from orange peel was $159 \%$ by using PEF treatment at power of $7 \mathrm{kV} / \mathrm{cm}$ (Luengo et al. 2013).

The yield of phenolic compounds (102.86 mg GAE $\left.100 \mathrm{~g}^{-1} \mathrm{FW}\right)$ and flavonoid compounds (37.58 mg QE $100 \mathrm{~g}^{-1} \mathrm{FW}$ ) from onion was enhanced significantly by 2.2 and 2.7 times, respectively, as compared to control samples. It is an environmentally friendly process that can be used at large scale for the extraction of high-valued bioactive compounds (Liu et al. 2018). Onions are rich in phenols and flavonoids; thus, PEF is one of the most suitable non-thermal methods for the extraction of these valued components without a significant loss in their property. The electric field intensity and extraction time had a significant effect on the yield of both phenolic and flavonoid compounds. The occurrence of cytomembrane in the cell wall of plant tissue affects the migration of the intracellular substances between the cells. Hence, PEF is the promising strategy for the extraction of bioactive compounds, since it causes the disintegration of the cytomembrane in the tissues, which changes the permeability properties and increases the mass transfer across the cells, thereby resulting in higher yields.

This technology not only enhances the rate of extraction of anthocyanins, betanines, carotenoids, etc., from natural food sources and their by-products, but also lessens the time and solvent quantity and/or lower temperature values of extraction (Boussetta et al. 2012; Puértolas et al. 2013). The most remarkable feature of this technology is that being non-thermal in nature, it does not affect the quality of the final product. Moreover, it can be used for continuous processes either in pilot scale or at industrial level. Thus, it is one of the cost-effective emerging technologies that can be used in food processing sectors for large-scale processes.

\section{Enzyme-assisted extraction}

It is counted as the novel technology and is considered as an alternative to conventional technique for extraction of various valuable components due to the use of water as solvent rather than organic chemicals (Puri et al. 2012). This technique is generally used when the phytochemicals are scattered in the cell cytoplasm and the presence of hydrogen or hydrophobic bonds in the polysaccharidelignin network, thus posing a difficulty in extraction by conventional techniques. Despite this, because of its sustainable, eco-friendly nature and higher yield of the product, this technique has received more attention in last few years (Puri et al. 2012).

Enzyme concentration, composition, particle size, water-to-solid ratio and hydrolysis time are some of the major factors that influence the enzyme-assisted extraction of various bioactive compounds (Puri et al. 2012). This technique has been explored for the extraction of various components, such as carotenoids from pumpkin (Ghosh and Biswas 2015), anthocyanins from crocus sativus (Lotfi et al. 2015) and anthocyanin from grape skin. (Muñoz et al. 2004). Further, the yield of phenolics extracted from grape mare seeds was found to be $18-20 \mathrm{mg} / \mathrm{g}$ through pectinase (Štambuk et al. 2016), antioxidants phenols $(0.152 \mathrm{mg} / \mathrm{g})$ from apple pomace by Pectinex ${ }^{\circledR}$ (Oszmiański et al. 2011) and 
phenolics concentration (86.6\%) from grape residues using Celluclast ${ }^{\circledR}$ (Gómez-García et al. 2012). Therefore, this extraction technique is very effective to enhance the recovery of compounds by using enzymes such as pectinase, cellulase and protease. However, cost of the enzyme is the limitation of this technique that hinders the scaleup process and further limits the yield of the final product. However, the cost can be reduced by immobilization technique that facilitates the reusability of the enzyme without loss in its specificity and activity (Puri et al. 2012).

\section{Nanoemulsions-based delivery system for bioactive compounds and their applications in food systems}

In today's scenario, consumption of healthy and nutritive food ingredients having functional properties is prerequisite in our diet. With changing pattern of living style of people, focus has been shifted towards the nanotechnology. Nanotechnology has numerous applications in different sectors, and nanoemulsions-based delivery system has potential applications for the effective delivery of functional compounds in food sector.

Nanoemulsions are the mini-emulsions which have the particle size in the range of $100 \mathrm{~nm}$. Nanoemulsions are kinetically stable, of small droplet size (high surface area per unit volume), optically transparent but thermodynamically unstable and act as the improved delivery system for different applications. It involves the dispersion of oil droplets in the aqueous phase along with suitable emulsifier, having droplet size in the range of $20-100 \mathrm{~nm}$. If nanoemulsions are formed without using an emulsifier, the system immediately undergoes the different mechanisms such as Ostwald ripening, flocculation, gravitational separation and coalescence (McClements and Rao 2011). There are different approaches to design the nanoemulsions, and it depends upon different factors such as desirable end product, total energy requirement and storage conditions. Nanoemulsions are obtained by two main approaches called high energy and low energy as indicated in Table 3.

These nanoemulsions have different physico-chemical and functional properties depending upon their compositional ingredients and method of formation (low-energy or high-energy methods). Low-energy methods used for formation of nanoemulsions are spontaneous emulsification, phase inversion point, membrane emulsification, emulsion inversion point and solvent displacement. Nanoemulsions are formed by different mechanisms such as surface tension gradient, condensation mechanism, interfacial turbulence, dispersion mechanism and diffusion of solutes between two phases in spontaneous emulsification method.
Phase inversion point is the method in which transitional phase inversion takes place along with temperature change (thermal) at fixed composition. In this method, nanoemulsions formation takes place over a wide range of temperatures instead of fixed temperature along with energy saving and having the capability to involve the heat-sensitive compounds for food different applications while in emulsion inversion point, it undergoes phase inversion during emulsification process by changing the composition at constant temperature (isothermal). Membrane emulsification is the low-energy method which includes the formation of nanoemulsions by passing the dispersed phase through the membrane into a continuous phase. In the solvent displacement, the nanoemulsions form by rapid diffusion of the organic solvent in the aqueous phase and finally remove the organic phase under reduced pressure. All low-energy methods are simple and do not demand expensive equipments, but they require high surfactant-to-oil ratios (SORs) (Komaiko and McClements 2016). However, these low-energy techniques are potentially cost-effective strategy as compared to high-energy methods.

At present, applications of low-energy methods in food industries are limited due to the use of excessive amounts of synthetic surfactants than proteins or polysaccharides as emulsifiers. Some authors have also prepared nanoemulsions by spontaneous emulsification (Guttoff et al. 2015; An et al. 2014) and by emulsion inversion point (Hategekimana and Zhong 2015; Mayer et al. 2013).

High-energy approaches include high-pressure homogenization, ultrasonification and high-speed homogenization (Komaiko and McClements 2016). These methods for formation of nanoemulsions use the high intense force to rupture the large droplets into small ones by using the mechanical devices such as high-pressure homogenizers, microfluidizers, sonicators and high-speed devices (rotor/stator devices) (Kaci et al. 2018; Dey et al. 2018; Katsouli et al. 2018; Luo et al. 2017). This approach depends on many factors for obtaining the smallest size of the droplets such as operating conditions, homogenizer type and composition of a sample and physico-chemical properties of the different phases. In high-energy approach, less amount of SORs is used to form nanoemulsions as compared to the low-energy techniques. Nanoemulsions formed by high-energy techniques may be prone to Ostwald ripening but have better stability for coalescence and flocculation (McClements and Rao 2011). It can be controlled by adding compositional quantity such as ripening inhibitor. High-energy methods are more suitable in food industry because they can produce food grade nanoemulsions without using high SORs along with a 
Table 3 Examples of oil-in-water nanoemulsions by using different methods

\begin{tabular}{|c|c|c|c|c|}
\hline Bioactive component & Oil phase & Surfactant/co-surfactant & Particle diameter (nm) & References \\
\hline \multicolumn{5}{|c|}{ Ultrasonication/ultrasonication homogenizer } \\
\hline Curcumin & MCT & $\begin{array}{l}\text { Whey protein concen- } \\
\text { trate-70/Tween-80 }\end{array}$ & $141.6 \pm 15.4$ & Sari et al. (2015) \\
\hline Quercetin & Lemon oil/corn oil & Saponin, Tween-20 & $52 \pm 10$ & Kaur et al. (2016) \\
\hline Coenzyme $\mathrm{Q}_{10}\left(\mathrm{CoQ}_{10}\right)$ & $\begin{array}{l}\text { Rapeseed oil/rapeseed } \\
\text { lecithin }\end{array}$ & $\begin{array}{l}\text { Xanthan gum and carboxy- } \\
\text { methylcellulose sodium } \\
\text { salt (as a thickeners) }\end{array}$ & $<170$ & Kaci et al. (2018) \\
\hline $\begin{array}{l}\text { a) Lemon myrtle essential oil } \\
\text { (LMEO) } \\
\text { b) Anise myrtle essential oil } \\
\text { (AMEO) }\end{array}$ & - & Tween 80 & $\begin{array}{l}\text { LMEO }(\approx 16.07) \\
\text { AMEO }(\approx 30.23)\end{array}$ & Nirmal et al. (2018) \\
\hline \multicolumn{5}{|l|}{ High-pressure homogenizer } \\
\hline$\beta$-Carotene & MCT & $\begin{array}{l}\text { Modified starch, decaglyc- } \\
\text { erol monolaurate, Tween } \\
\text { 20, whey protein isolate }\end{array}$ & $115-178$ & Mao et al. (2009) \\
\hline Resveratrol and Curcumin & $\begin{array}{l}\text { Peanut oil, palm oil and } \\
\text { stearic acid }\end{array}$ & $\begin{array}{l}\text { Soy lecithin, sugar ester, } \\
\text { modified starch, vegeta- } \\
\text { bles protein }\end{array}$ & $<200$ & Donsì et al. (2011) \\
\hline$\omega$-3 PUFA in oil phase & Fish oil (EPA and DHA) & $\begin{array}{l}\text { Span } 80 \text {, Tween } 20 \\
\text { Sesame protein isolate } \\
\text { (Natural alternative sur- } \\
\text { factants) }\end{array}$ & $<100$ & Dey et al. (2018) \\
\hline \multicolumn{5}{|l|}{ High-speed homogenizer } \\
\hline $\begin{array}{l}\text { Olive oil endogenous phe- } \\
\text { nolic compounds (vanillic, } \\
\text { caffeic and syringic acid) }\end{array}$ & Extra virgin olive oil (EVOO) & Tween 20 & $>251$ & Katsouli et al. (2018) \\
\hline $\begin{array}{l}\text { Phenolic acids (gallic, syrin- } \\
\text { gic, vanillic acid) }\end{array}$ & Olive oil & Tween 20 & $<500$ & Polychniatou and Tzia (2018) \\
\hline $\begin{array}{l}\text { Eugenia brejoensis essential } \\
\text { oil }\end{array}$ & - & Tween 80 & $\begin{array}{l}355.63 \pm 21.70 \text { to } \\
143.13 \pm 1.1\end{array}$ & Mendes et al. (2018) \\
\hline \multicolumn{5}{|l|}{ Microfluidizer } \\
\hline$\beta$-Carotene & Corn oil & $\begin{array}{l}\text { Whey protein isolate, Quil- } \\
\text { laja saponins }\end{array}$ & $140-160$ & Luo et al. (2017) \\
\hline a-Tocopherol & MCT & $\begin{array}{l}\text { Glycerol, decaglycerol } \\
\text { monooleate soybean leci- } \\
\text { thin, glycerol SDS, Tween } \\
\text { 20, beta-lactoglobulin }\end{array}$ & $80-400$ & Hatanaka et al. (2010) \\
\hline \multicolumn{5}{|l|}{ Spontaneous emulsification } \\
\hline Capsanthin & MCT & Tween 80 and span 20 & $\approx 30-150$ & An et al. (2014) \\
\hline Vitamin D & MCT & $\begin{array}{l}\text { Tween } 80 \text {, or Tween } 85 / \\
\text { SDS Tween 20, Tween 60, } \\
\text { Tween } 40\end{array}$ & $\approx 100$ & Guttoff et al. (2015) \\
\hline \multicolumn{5}{|l|}{ Emulsion phase inversion } \\
\hline Vitamin E & MCT & $\begin{array}{l}\text { Tween 20, sucrose monopal- } \\
\text { mitate, Tween } 40 \text {, Tween } \\
\text { 85, Q-natural, casein, } \\
\text { Tween } 80 \text {, whey protein } \\
\text { isolate, Tween } 60\end{array}$ & $\approx 40$ & Mayer et al. (2013) \\
\hline Vitamin E & Tributyrin & Tween 80 & $\approx 110$ & $\begin{array}{l}\text { Hategekimana and Zhong } \\
\text { (2015) }\end{array}$ \\
\hline
\end{tabular}

wide range of different compositional entities (oil and emulsifier types) (McClements and Rao 2011). Therefore, according to their applicability, these techniques are used for the formation of nanoemulsions. Highand low-energy approaches have their own advantages and disadvantages.
The various applications of nanoemulsions in food sector include encapsulation of poorly soluble compounds (natural preserving agents, nutraceuticals, colourants, flavours), texture modification as well as enhancement in bioavailability, digestibility and solubility, etc. The nanoencapsulation of eugenol gave the 
highest nanoencapsulated yield as well as efficiency of 91.74 and $97.81 \%$, respectively. Further, it was also found that this nanoencapsulated essential oil improved the antioxidant and anti-microbial activity in foods (Khaled et al. 2014). Some industries have applied the nanoemulsions on their products to increase their functional value in different aspects such as nanoencapsulation of phytosterols (Shemen, Haifa, Israel) and functional compounds (Aquanova, Germany), natural colourant (Wild flavours and Specialty Ingredients Inc., USA), and development of low fat products (Martins et al. 2007; Unilever 2011).

Application of nanoemulsions in food systems has certain challenges in terms of production, its characterization, product safety, acceptance and economy of the process that needs to be addressed (Salem and Ezzat 2019; Khaled et al. 2014).

\section{Anti-microbial agent}

Food safety and quality are the major concerns of food applications. To fulfil these aspects, nanotechnology sector is concentrating on the essential oils which have an anti-microbial activity associated with their phenolic compounds. Numerous authors were reported, regarding the nanoemulsions which contain the essential oils (lemongrass, thyme, clove, geranium, tea tree, rosewood, marjoram, mint, palmarosa, sage) in their composition (Salvia-Trujillo et al. 2015). It is mainly believed that nanoemulsions that contained lipophilic anti-microbials would be able to improve bactericidal effect by penetrating into microbial membranes more easily (Salvia-Trujillo et al. 2015). Therefore, these essential oils containing nanoemulsions are the good alternative to synthetic additives in terms of better anti-microbial, anti-fungal and anti-viral activity that further improves the shelf life (Shaaban et al. 2012). However, further research is required for correlating the relationship between the anti-microbial activities with different properties of nanoemulsions.

\section{Delivery of poorly soluble drugs}

Nanoemulsions are used for encapsulating the bioactive compounds which include $\beta$-carotene, lutein, quercetin, curcumin, resveratrol, capsanthin and vitamin $E$ because these systems are well known to enhance the bioactivity, solubility, kinetic and physical stability (Surh et al. 2017; Sari et al. 2015; Kaur et al. 2016; Mao et al. 2009; Donsì et al. 2011; An et al. 2014; Hategekimana and Zhong 2015).

\section{Modification of texture}

Apart from delivery of bioactive compounds, these nanoemulsions have wide scope for modification of texture in food industries. Food industries like Unilever reduced the fat content (16\% to $1 \%$ ) of ice cream through nanoemulsions. In nanoemulsions, phenomenon of gelation is possible at low concentration of fat as compared to the emulsions. This property could be effective in food industries for producing the products like dressings, mayonnaise, etc., along with their desirable texture and flavour. However, it is required to focus on more researches which are related to edible systems and use their different functions for developing the new products and processes in food industry.

\section{Conclusion and future prospective}

Fruits and vegetables processing industry produces huge amount of waste that is rich in bioactive compounds. These bioactive compounds can be further utilized as natural colouring, antioxidant, preservative and anti-microbial agents in different industries. By using nanoencapsulation techniques such as nanoemulsions, the functional and textural properties of these bioactive compounds can be enhanced in food systems. Extraction of bioactives from wastes has been carried out using various non-conventional techniques; however, there is need for the development of novel and efficient techniques for the recovery of bioactive compounds. Among all, ultrasound-assisted extraction has significant applications in terms of higher yield, desirable quality, simple process and environmental friendly nature. In food processing sector, nanoemulsions are important delivery system for different bioactive compounds, which perform various functions such as increase their bioavailability, control the release of the ingredient, modulate the product texture and protect the ingredient from degradation in a better way. Although an intensive research is being carried on different extraction techniques and delivery system loaded with bioactive compounds, further research is required for better understanding for the specific function of bioactive compounds in particular food-based delivery system and its bioavailability in the body. A more comprehensive understanding is desirable for the bioaccessibility, metabolism and absorption of the encapsulated compound due to the alterations in their properties by taking place through the gastrointestinal tract. An extensive research should be done on the loading capacity of bioactive compounds encapsulated in nanoemulsions and their release characteristics. Therefore, it is critical to reduce the environmental pollution by extracting the bioactive compounds from fruits and vegetables waste which can further replace the synthetic antioxidant in various industries. 


\section{Abbreviations}

F\&Vs: fruits and vegetables; MMT: million metric tonnes; SFE: supercritical fluid extraction; PEF: pulsed electric field; SOR: surfactant-to-oil ratio; UAE: ultrasound-assisted extraction; GAE: gallic acid equivalents; DW: dry weight; UAE: ultrasound-assisted extraction; MCT: medium-chain triglycerides.

\section{Acknowledgements}

Not applicable.

\section{Authors' contributions}

All authors have read and approved the final manuscript.

\section{Funding}

This work has not received any funding.

\section{Availability of data and materials}

Not applicable.

\section{Ethics approval and consent to participate}

Not applicable.

\section{Consent for publication}

Authors have approved to submit this manuscript to Bioresources and Bioprocessing.

\section{Competing interests}

The authors declare no competing interests.

Received: 19 April 2019 Accepted: 9 July 2019

Published online: 25 July 2019

\section{References}

Abdelkarim G (2014) What is a bioactive compounds? A combined definition for a preliminary consensus. Int J Nutr Food Sci 3:174-179

Agócs A, Nagy V, Szabó Z, Márk L, Ohmacht R, Deli J (2007) Comparative study on the carotenoid composition of the peel and the pulp of different citrus species. Innov Food Sci Emerg Technol 8(3):390-394

Ajila CM, Aalami M, Leelavathi K, Rao UP (2010) Mango peel powder: a potential source of antioxidant and dietary fiber in macaroni preparations. Innov Food Sci Emerg Technol 11:219-224

Alupului A, Čalinescu I, Lavric V (2012) Microwave extraction of active principles from medicinal plants. UPB Sci Bull Ser B Chem Mater Sci 74:129-142

Ameer K, Shahbaz HM, Kwon JH (2017) Green extraction methods for polyphenols from plant matrices and their byproducts: a review. Compr Rev Food Sci Food Saf 16:295-315

An Y, Yan X, Li B, Li Y (2014) Microencapsulation of capsanthin by self-emulsifying nanoemulsions and stability evaluation. Eur Food Res Technol 239:1077-1085

Azmir J, Zaidul ISM, Rahman MM, Sharif KM, Mohamed A, Sahena F, Jahurul MHA, Ghafoor K, Norulaini NAN, Omar AKM (2013) Techniques for extraction of bioactive compounds from plant materials: a review. J Food Eng 117:426-436

Bobinaitè R, Pataro G, Lamanauskas N, Šatkauskas S, Viškelis P, Ferrari G (2015) Application of pulsed electric field in the production of juice and extraction of bioactive compounds from blueberry fruits and their by-products. J Food Sci Technol 52:5898-5905

Boussetta N, Vorobiev E, Le LH, Cordin-Falcimaigne A, Lanoisselle JL (2012) Application of electrical treatments in alcoholic solvent for polyphenols extraction from grape seeds. LWT-Food Sci Technol 46:127-134

Bryant G, Wolfe J (1987) Electromechanical stress produced in the plasma membranes of suspended cells by applied electrical fields. J Membr Biol 96:129-139

Chandrasekar V, Martín-González MFS, Hirst P, Ballard TS (2015) Optimizing microwave-assisted extraction of phenolic antioxidants from red delicious and jonathan apple pomace. J Food Process Eng 38:571-582

Chanfrau CJER, Armas TML (2014) Ultrasound assisted extraction of polyphenols from Punica granatum (Grenada) fruits. Rev Cuba Farm 48:469-476
Chen C, You LJ, Abbasi AM, Fu X, Liu RH (2015) Optimization for ultrasound extraction of polysaccharides from mulberry fruits with antioxidant and hyperglycemic activity in vitro. Carbohydr Polym 130:122-132

Chuyen HV, Nguyen MH, Roach PD, Golding JB, Parks SE (2017) Microwaveassisted extraction and ultrasound-assisted extraction for recovering carotenoids from gac peel and their effects on antioxidant capacity of the extracts. Food Sci Nutr 6:189-196

Corrales M, Toepfl S, Butz P, Knorr D, Tauscher B (2008) Extraction of anthocyanins from grape by-products assisted by ultrasonics, high hydrostatic pressure or pulsed electric fields: a comparison. Innov Food Sci Emerg Technol 9:85-91

Datta AK, Sumnu G, Raghavan GSV (2005) Dielectric properties of foods. In: Rao MA, Rizvi SSH and Datta AK (eds) Engineering properties of foods, 3rd edn. Taylor \& Francis, Boca Raton

Delsart C, Ghidossi R, Poupot C, Mietton-Peuchot M (2012) Enhanced extraction of phenolic compounds from merlot grapes by pulsed electric field treatment. Am J Enol Viticult 63:205-211

Deng GF, Shen C, Xu XR, Kuang RD, Guo YJ, Zeng LS, Gao LL, Lin X, Xie JF, Xia EQ, Li S, Wu S, Chen F, Ling WH, Li HB (2012) Potential of fruits waste as natural resources of bioactive compounds. Int J Mol Sci 13:8308-8323

Dey TK, Banerjee P, Chatterjee R, Dhar P (2018) Designing of $\omega$-3 PUFA enriched biocompatible nanoemulsion with sesame protein isolate as a natural surfactant: focus on enhanced shelf-life stability and biocompatibility. Colloids Surf A Physicochem Eng Asp 538:36-44

Dhobi M, Mandal V, Hemalatha S (2009) Optimization of microwave-assisted extraction of bioactive flavonolignan - silybinin. J Chem Metrl 3:13-23

Donsi F, Sessa M, Mediouni H, Mgaidi A, Ferrari G (2011) Encapsulation of bioactive compounds in nanoemulsionbased delivery system. Procedia Food Sci 1:1666-1671

Drosou C, Kyriakopoulou K, Bimpilas A, Tsimogiannis D, Krokida M (2015) A comparative study on different extraction techniques to recover red grape pomace polyphenols from vinification byproducts. Ind Crops Prod 75:141-149

Espinosa-Pardo FA, Nakajima VM, Macedo GA, Macedo JA, Martínez J (2017) Extraction of phenolic compounds from dry and fermented orange pomace using supercritical $\mathrm{CO}_{2}$ and cosolvents. Food Bioprod Process 101:1-10

FAO (2014) Definitional framework of food losses and waste. Italy, Rome

Ferarsa S, Zhang W, Moulai-Mostefa N, Ding L, Jaffrin MY, Grimi N (2018) Recovery of anthocyanins and other phenolic compounds from purple eggplant peels and pulps using ultrasonic-assisted extraction. Food Bioprod Process 109:19-28

Freedman ND, Park Y, Subar AF, Hollenbeck AR, Leitzmann MF, Schatzkin A, Abnet CC (2008) Fruits and vegetable intake and head and neck cancer risk in a large United States prospective cohort study. Int J Cancer 122:2330-2336

Garcia-Castello EM, Rodriguez-Lopez AD, Mayor L, Ballesteros R, Conidi C, Cassano A (2015) Optimization of conventional and ultrasound assisted extraction of flavonoids from grapefruits (Citrus paradisi L.) solid wastes. LWT Food Sci Technol 64:1114-1122

Genkinger JM, Platz EA, Hoffman SC, Comstock GW, Helzlsouer KJ (2004) Fruits, vegetable, and antioxidant intake and all-cause, cancer, and cardiovascular disease mortality in a community-dwelling population in Washington County, Maryland. Am J Epidemiol 160:1223-1233

Ghafoor K, Choi YH, Jeon JY, Jo IH (2009) Optimization of ultrasound-assisted extraction of phenolic compounds, antioxidants, and anthocyanins from grape (Vitis vinifera) seeds. J Agric Food Chem 57:4988-4994

Ghosh D, Biswas PK (2015) Enzyme-aided extraction of carotenoids from pumpkin tissues. Indian Chem Eng 58:1-11. https://doi. org/10.1080/00194506.2015.1046697

Giannuzzo AN, Boggetti HJ, Nazareno MA, Mishima HT (2003) Supercritical fluid extraction of naringin from the peels of citrus paradise. Phytochem Anal 14:221-223

Gómez-García R, Martínez-Ávila GCG, Aguilar CN (2012) Enzyme assisted extraction of antioxidative phenolics from grape (Vitis vinifera L.) residues. 3 Biotech 2:297-300

Guttoff M, Saberi AH, McClements DJ (2015) Formation of vitamin D nanoemulsion-based delivery systems by spontaneous emulsification: factors affecting particle size and stability. Food Chem 171:117-122

Hatanaka J, Chikamori H, Sato H, Uchida S, Debari K, Onoue S, Yamada S (2010) Physicochemical and pharmacological characterization 
of alpha-tocopherol-loaded nano-emulsion system. Int J Pharm 396:188-193

Hategekimana J, Zhong F (2015) Degradation of vitamin E in nanoemulsions during storage as affected by temperature, light and darkness. Int J of Food Eng 11:199-206

Heinz V, Toepfl S, Knorr D (2003) Impact of temperature on lethality and energy efficiency of apple juice pasteurization by pulsed electric fields treatment. Innov Food Sci Emerg Technol 4:167-175

Inoue T, Tsubaki S, Ogawa K, Onishi K, Azuma JI (2010) Isolation of hesperidin from peels of thinned Citrus unshiu fruits by microwave-assisted extraction. Food Chem 123:542-547

Kaci M, Belhaffef A, Meziane S, Dostert G, Menu P, Velot E, Desobry S, ArabTehrany E (2018) Nanoemulsions and topical creams for the safe and effective delivery of lipophilic antioxidant coenzyme Q10. Colloids Surf B: Biointerfaces 167:165-175

Kallel F, Driss D, Chaari F, Belghitha L, Bouaziz F, Ghorbel R, Chaabouni SE (2014) Garlic (Allium sativum L.) husk waste as a potential source of phenolic compounds: influence of extracting solvents on its antimicrobial and antioxidant properties. Ind Crops Prod 62:34-41

Katsouli M, Polychniatou V, Tzia C (2018) Optimization of water in olive oil nano-emulsions composition with bioactive compounds by response surface methodology. LWT-Food Sci Technol 89:740-748

Kaur K, Kumar R, Mehta SK (2016) Formulation of saponin stabilized nanoemulsion by ultrasonic method and its role to protect the degradation of quercitin from UV light. Ultrason Sonochem 31:29-38

Kehili M, Kammlott M, Choura S, Zammel A, Zetzl C, Smirnova I, Allouche N, Sayadi S (2017) Supercritical $\mathrm{CO}_{2}$ extraction and antioxidant activity of lycopene and $\beta$-carotene-enriched oleoresin from tomato (Lycopersicum esculentum L.) peels by-product of a Tunisian industry. Food Bioprod Process 102:340-349

Kentish S, Feng H (2014) Applications of power ultrasound in food processing. Annu Rev Food Sci Technol 5:263-284

Khaled FM, Khaled MAR, Ashoush IS (2014) Nanoencapsulation and nanoemulsion of bioactive compounds to enhance their antioxidant activity in food. IJFST 4:1-22

Komaiko JS, McClements DJ (2016) Formation of food -grade nanoemulsions using low-energy preparation methods: a review of available methods. Compr Rev Food Sci Food Saf 15:331-352

Krishnan RY, Rajan KS (2016) Microwave assisted extraction of flavonoids from Terminalia bellerica: study of kinetics and thermodynamics. Sep Purif Technol 157:169-178

Kujala TS, Loponen JM, Klika KD, Pihlaja K (2000) Phenolics and betacyanins in red beetroot (Beta vulgaris) root: distribution and effect of cold storage on the content of total phenolics and three individual compounds. J Agri Food Chem 48:5338-5342

Leontowicz H, Leontowicz M, Gorinsteinolga S, Martin-Belloso O, Trakhtenberg S (2007) Apple peels and pulp as a source of bioactive compounds and their influence on digestibility and lipid profile in normal and atherogenic rats. Medycyna weterynaryjna 63:1434-1436

Liu RH (2013) Dietary Bioactive compounds and their health implications. J Food Sci 78:A18-A25

Liu ZW, Zeng XA, Ngadi M (2018) Enhanced extraction of phenolic compounds from onion by pulsed electric field (PEF). J Food Process Preserv. https://doi.org/10.1111/jfpp.13755

López N, Puértolas E, Condón S, Álvarez I, Raso J (2008) Effects of pulsed electric fields on the extraction of phenolic compounds during the fermentation of must of Tempranillo grapes. Innov Food Sci Emerg Technol 9:477-482

Lotfi L, Kalbasi-Ashtari A, Hamedi M, Ghorbani F (2015) Effects of enzymatic extraction on anthocyanins yield of saffron tepals (Crocos sativus) along with its color properties and structural stability. J Food Drug Anal 23:210-218

Luengo E, Alvarez I, Raso J (2013) Improving the pressing extraction of polyphenols of orange peel by pulsed electric fields. Innov Food Sci Emerg Tech 17:79-84

Luengo E, Condón-Abanto S, Condón S, Álvarez I, Raso J (2014) Improving the extraction of carotenoids from tomato waste by application of ultrasound under pressure. Sep Purif Technol 136:130-136

Luo X, Zhou Y, Bai L, Liu F, Deng Y, McClements DJ (2017) Fabrication of $\beta$-carotene nanoemulsion-based delivery systems using dual-channel microfluidization: physical and chemical stability. J Colloid Interface Sci 490:328-335

Ma YQ, Ye XQ, Fang ZX, Chen JC, Xu GH, Liu DH (2008) Phenolic compounds and antioxidant activity of extracts from ultrasonic treatment of satsuma mandarin (Citrus unshiu Marc.) peels. J Agric Food Chem 56:5682-5690

Manna L, Bugnone CA, Banchero M (2015) Valorization of hazelnut, coffee and grape wastes through supercritical fluid extraction of triglycerides and polyphenols. J Supercrit Fluid 104:204-211

Mao L, Xu D, Yang J, Yuan F, Gao Y, Zhao J (2009) Effects of small and large molecule emulsifiers on the characteristics of beta-carotene nanoemulsions prepared by high pressure homogenization. Food Technol Biotech 47:336-342

Martins P, Dulley R, Ramos S, Barbosa M, Assumpção R, Junior S, Lacerda A (2007) Nanotecnologias na indústria de alimentos. http://www.pucsp.br/ eitt/downloads/vi_ciclo_paulomartins_marisabarbosa_nano_puc.pdf. Accessed 14 Apr 2011

Mayer S, Weiss J, McClements DJ (2013) Vitamin E-enriched nanoemulsions formed by emulsion phase inversion: factors influencing droplet size and stability. J Colloid Interface Sci 402:122-130

McClements DJ, Rao J (2011) Food-grade nanoemulsions: formulation, fabrication, properties, performance, biological fate, and potential toxicity. Crit Rev Food Sci Nutr 51:285-330

Mendes JF, Martins HHA, Otoni CG, Santana NA, Silva RCS, Da Silva AG, Silva MV, Correia MTS, Machado G, Pinheiro ACM, Piccoli RH, Oliveira JE (2018) Chemical composition and antibacterial activity of Eugenia brejoensis essential oil nanoemulsions against Pseudomonas fluorescens. LWT Food Sci Technol. https://doi.org/10.1016/j.lwt.2018.04.015

Moo-Huchin VM, Moo-Huchin MI, Estrada-León RJ, Cuevas-Glory L, EstradaMota IA, Ortiz-Vázquez E, Betancur-Ancona D, Sauri-Duch E (2015) Antioxidant compounds, antioxidant activity and phenolic content in peel from three tropical fruits from Yucatan, Mexico. Food Chem 166:17-22

Moreira MM, Barroso MF, Boeykens A, Withouck H, Morais S, Delerue-Matos C (2017) Valorization of apple tree wood residues by polyphenols extraction: comparison between conventional and microwave-assisted extraction. Ind Crops Prod 104:210-220

Muñoz O, Sepulveda M, Schwartz M (2004) Effects of enzymatic treatment on anthocyanic pigments from grapes skin from Chilean wine. Food Chem 87:487-490

Nath P, Kaur C, Rudra SG, Varghese E (2016) Enzyme assisted extraction of carotenoid-rich extract from red capsicum (Capsicum annuum). Agric Res 5:193-204

Nayak B, Dahmoune F, Moussi K, Remini H, Dairi S, Aoun O, Khodir M (2015) Comparison of microwave, ultrasound and accelerated-assisted solvent extraction for recovery of polyphenols from citrus sinensis peels. Food Chem 187:507-516

Nirmal NP, Mereddy R, Li L, Sultanbawa Y (2018) Formulation, characterisation and antibacterial activity of lemon myrtle and anise myrtle essential oil in water nanoemulsion. Food Chem 254:1-7

Oszmiański J, Wojdyło A, Kolniak J (2011) Effect of pectinase treatment on extraction of antioxidant phenols from pomace, for the production of puree-enriched cloudy apple juices. Food Chem 127:623-631

Panouillé M, Ralet MC, Bonnin E, Thibault JF (2007) Recovery and reuse of trimmings and pulps from fruits and vegetable processing. In: Waldron KW (ed) Handbook of waste management and co-product recovery in food processing, vol 1. Woodhead Publishing Limited, Cambridge, pp 417-447

Parfitt J, Barthel M, Macnaughton S (2010) Food waste within food supply chains: quantification and potential for change to 2050. Philos Trans R Soc B 365:3065-3081

Polychniatou V, Tzia C (2018) Evaluation of surface-active and antioxidant effect of olive oil endogenous compounds on the stabilization of waterin-olive-oil nanoemulsions. Food Chem 240:1146-1153

Puértolas E, López N, Saldaña G, Álvarez I, Raso JE (2010) Evaluation of phenolic extraction during fermentation of red grapes treated by a continuous pulsed electric fields process at pilot-plant scale. J Food Eng 98:120-125

Puértolas E, Cregenzán O, Luengo E, Álvarez I, Raso J (2013) Pulsed electricfield-assisted extraction of anthocyanins from purple-fleshed potato. Food Chem 136:1330-1336

Puri M, Sharma D, Barrow CJ (2012) Enzyme-assisted extraction of bioactives from plants. Trends Biotechnol 30:37-44

Routray W, Orsat V (2011) Blueberries and their anthocyanins: factors affecting biosynthesis and properties. Comp Rev Food Sci Food Saf 10:303-320 
Rozzi NL, Singh RK, Vierling RA, Watkins BA (2002) Supercritical fluid extraction of lycopene from tomato processing by products. J Agric Food Chem 50:2638-2643

Salem MA, Ezzat SM (2019) Nanoemulsions in food industry. In: Milani J (ed) Some new aspects of colloidal systems in foods. IntechOpen, United Kingdom

Salvia-Trujillo L, Rojas-Graü A, Soliva-Fortuny R, Martín-Belloso O (2015) Physicochemical characterization and antimicrobial activity of foodgrade emulsions and nanoemulsions incorporating essential oils. Food Hydrocoll 43:547-556

Sari TP, Mann B, Kumar R, Singh RRB, Sharma R, Bhardwaj M, Athira S (2015) Preparation and characterization of nanoemulsion encapsulating curcumin. Food Hydrocoll 43:540-546

Schieber A, Stintzing FC, Carle R (2001) By-products of plant food processing as a source of functional compounds-recent developments. Trends Food Sci Technol 12:401-413

Shaaban HAE, El-Ghorab AH, Shibamoto T (2012) Bioactivity of essential oils and their volatile aroma components: review. J Essent Oil Res 24:203-212

Shen X, Shao S, Guo M (2017) Ultrasound-induced changes in physical and functional properties of whey proteins. Int J Food Sci Technol 52:381-388

Simić VM, Rajković KM, Stojičević SS, Veličković DT, Nikolić NČ, Lazić ML, Karabegović IT (2016) Optimization of microwave assisted extraction of total polyphenolic compounds from chokeberries by response surface methodology and artificial neural network. Sep Purif Technol 160:89-97

Sivakumar V, Vijaeeswarri J, Anna JL (2011) Effective natural dye extraction from different plant materials using ultrasound. Ind Crops Prod 33:116-122

Sivakumar V, Ilanhtiraiyan S, Ilayaraja K, Ashly A, Hariharan S (2014) Influence of ultrasound on avaram bark (Cassia auriculata) tannin extraction and tanning. Chem Eng Res Des 92:1827-1833

Štambuk P, Tomašković D, Tomaz I, Maslov L, Stupić D, Karoglan Kontić J (2016) Application of pectinases for recovery of grape seeds phenolics. 3 Biotech 6:224. https://doi.org/10.1007/s13205-016-0537-0

Studdert V, Gay C, Blood D (2011) Saunders comprehensive veterinary dictionary. Elsevier Health Sciences, United Kingdom
Surh J, Decker EA, McClements DJ (2017) Utilisation of spontaneous emulsification to fabricate lutein-loaded nanoemulsion-based delivery systems: factors influencing particle size and colour. Int J Food Sci Technol 52:1408-1416

Unilever (2011) http://www.unilever.com/innovation/productinnovations/ coolicecreaminnovations/?WT.LHNAV=Cool_ice_cream_innovations. Accessed 13 Apr 2011

USDA Human Nutrition Information Service (2010) Dietary guidelines for Americans 2010, Hyattsville, MD

Vilariño MV, Franco C, Quarrington C (2017) Food loss and waste reduction as an integral part of a circular economy. Front Environ Sci 5:1-5

Virot M, Tomao V, Bourvellec CL, Renard KMCG, Chemat F (2010) Towards the industrial production of antioxidants from food processing by-products with ultrasound-assisted extraction. Ultrason Sonochem 17:1066-1074

Wang YC, Chuang YC, Hsu HW (2008) The flavonoid, carotenoid and pectin content in peels of citrus cultivated in Taiwan. Food Chem 106:277-284

Wu JJ, Lin JC, Wang CH, Jong TT, Yang HL, Hsu SL, Chieh-ming JC (2009) ExtraCtion of antioxidative compounds from wine lees using supercritical fluids and associated anti-tyrosinase activity. J Supercrit Fluid 50:33-41

Zhang W, Yao Y, Sullivan N, Chen Y (2011) Modeling the primary size effects of citrate-coated silver nanoparticles on their ion release kinetics. Environ Sci Technol 45:4422-4428

Zhang ZH, Wang LH, Zeng XA, Zhong H, Brennan CS (2018) Non-thermal technologies and its current and future application in the food industry: a review. Int J Food Sci Technol 54:1-13

Živković J, Šavikin K, Janković T, Ćujić N, Menković N (2018) Optimization of ultrasound-assisted extraction of polyphenolic compounds from pomegranate peel using response surface methodology. Sep Purif Technol 194:40-47

\section{Publisher's Note}

Springer Nature remains neutral with regard to jurisdictional claims in published maps and institutional affiliations.

\section{Submit your manuscript to a SpringerOpen ${ }^{\circ}$ journal and benefit from:}

- Convenient online submission

- Rigorous peer review

- Open access: articles freely available online

- High visibility within the field

Retaining the copyright to your article

Submit your next manuscript at $\boldsymbol{\nabla}$ springeropen.com 